\title{
The Death of the Fifth Earl of Derby: Cunning Folk and Medicine in Early Modern England
}

\author{
JUDITH BONZOL \\ University of Sydney
}

Les devins ont joué un rôle indispensable dans le diagnostique et la guérison de maladies d'origine diabolique dans les communautés anglaises des débuts de la modernité. Malgré les tentatives du clergé de les faire passer pour les agents du Diable, leur popularité est restée intacte. Les solutions proposées par l'église Protestante - la prière, le jeune et la piété - se sont avérés impuissantes face à la multitude d'afflictions étranges et déconcertantes infestant la campagne anglaise. Bien que les diagnostiques de ces personnes rusées ont parfois conduit à des accusations de sorcellerie, leur pratique sest souvent avérée préférable aux traitements invasifs et radicaux appliqués par les médecins gradués de l'université. La croyance populaire dans la capacité magique de guérison des devins était en partie favorisée par leur soutien par les élites. L'examen détaillé de la maladie soudaine et de la mort en 1594 de Ferdinando Stanley, cinquième comte de Derby, montre que l'emploi de ces intervenants nétait pas une pratique limitée aux pauvres et aux ignorants, et explore la nature des relations entre la médecine contrôlée par l'université et ce type de pratique.

n April 1594, Ferdinando Stanley, the fifth Earl of Derby, died suddenly and
unexpectedly in mysterious circumstances. Because he was a contender to the English throne, his contemporaries considered the possibility of poisoning. ${ }^{1}$ But the best-known account of his death tells us that "many learned men ... suppose[d] him to be bewitched." ${ }^{2}$ Current thinking invariably attributes the Earl's death to poison. A recent article in The Lancet entitled "Why did the $5^{\text {th }}$ Earl of Derby die?" argues specifically in favour of arsenic poisoning, even though his symptoms were not quite consistent with this scenario. ${ }^{3}$ Nevertheless, the proposition of poisoning is reasonable. These were the twilight years of Elizabeth's reign and, with no clear line of succession, many conspiracies 
were afoot. Poisonings were quite common. ${ }^{4}$ But Stanley's true cause of death remains unknown and allegations of poisoning were never substantiated. More importantly, the presence of a wise woman in the Earl's chamber allows a consideration of why cunning folk, otherwise known as wise men and women, blessers, or healers, continued to be consulted by people from all levels of early modern English society, despite concerted and persistent attempts by the Anglican clergy to label them as pernicious agents of the Devil.

Amidst the political, social, and religious turmoil associated with Queen Elizabeth's accession to the throne, the Marion exiles returned to England, and, late in the 1550s, initiated more rigorous moves to prohibit magical practices. ${ }^{5}$ Concerned with a rampant escalation in the numbers of witches and supernatural afflictions plaguing English communities, religious authorities were equally disconcerted by an accompanying proliferation of cunning folk. Bishop Jewel of Salisbury, after completing an extensive and exhausting visitation tour in 1559, pleaded with the Queen to implement appropriate laws to deal with the "malefactors." He expressly linked his concern about witchcraft to the manifestation of illnesses with unusual and rather disturbing symptoms: "Your graces subjectes pine away even unto the death, their colour fadeth, their flesh rotteth, their speach is benummed, their sences are bereft." ${ }^{\prime}$ Alarm over Catholic recusancy, and problems with establishing religious settlement, thus contributed to growing concern by the authorities about the popularity of cunning folk in England. Cunning folk certainly appeared more prevalent after the Reformation, judging by the vociferous protests of the authorities that drew attention to their presence.

Cunning folk, though, predate the Reformation, their antecedents tracing back at least as far as the Anglo-Saxons. ${ }^{7}$ They were numerous in the villages and towns throughout early modern England. ${ }^{8}$ They offered to tell fortunes, find lost or stolen objects and buried treasure, and create love potions-magical solutions to problems that people encountered in daily life-and were sought for their healing powers at times of crisis. Through magic, they fulfilled a need in the community that was not being met elsewhere. Illness was a site of particular conflict with authorities. In clerical writing, literary works, court proceed- 
ings, medical records, pamphlets, and elsewhere, the part cunning folk played in the diagnosis and treatment of supernatural afflictions-illnesses believed to be caused by witchcraft-is in clear evidence. Thus it developed that while concern about witchcraft intensified in the second half of the sixteenth century, cunning folk were becoming increasingly valued.

The Church of England hierarchy was disconcerted by rising instances of perceived supernatural afflictions-in part because public exorcisms attracted unwanted publicity. ${ }^{9}$ Exorcisms, in the Church of England view, were socially disruptive opportunities for proselytizing by both Catholics and godly, zealous Protestants, or "Puritans" as they were known to their detractors. In late sixteenth-century England, however, demonic possession was almost exclusively attributed to witchcraft. Cunning folk were sought for their unique magical healing and protection. ${ }^{10}$ This was particularly perplexing for the high Anglican clergy, who regarded cunning folk as perpetrators of "superstitious" Catholic beliefs and practices. ${ }^{11}$ Therefore, much of the abuse directed at cunning folk by religious writers at this time was akin to vitriolic rhetoric against exorcism and other "superstitious" practices that were associated with the old religion. This essay argues that the ability of the Church of England and university-educated physicians to help supernaturally afflicted people with approved healing rituals and medical treatments was fraught with problems; problems that cunning folk seemed equipped to evade. Furthermore, the attitude of elites towards cunning folk was ambivalent, which undermined the combined onslaught of civil and ecclesiastical authorities. Cunning folk were available to everybody, and their reputed ability to expel evil spirits and combat witches made them very popular.

Cunning folk, then, played a central role in the diagnosis and treatment of supernatural illness, a role that has received little consideration from historians. While scholarship on early modern medical practice has progressed from its traditional emphasis on university-educated physicians, and now incorporates a much wider range of practitioners in its scope, cunning folk have been largely ignored. ${ }^{12}$ As the historian of witchcraft and medicine Willem de Blécourt has remarked, "studying witchcraft and neglecting cunning folk would be comparable to studying medicine without considering doctors." ${ }^{13}$ And yet, with the exception of recent works by Owen Davies and Emma Wilby, cunning folk remain an area neglected by academic scholars. ${ }^{14}$ Building on the seminal work of Keith Thomas and Alan Macfarlane, Davies's recent and thorough documenta- 
tion traces the pervasive presence of cunning folk in English communities well into the nineteenth century. ${ }^{15}$

While cunning folk, as a social group distinct from witches, may have been neglected by academic scholars, substantial consideration has been given to the importance of social relationships, community and neighbourhood, witchcraft, and illness. At the popular level, unusual and sudden illnesses were often believed to be caused by people within the community, usually women, who had a reputation for witchcraft. ${ }^{16}$ This reputation, often acquired over many years, would culminate in a formal accusation of witchcraft when a neighbourhood dispute was accompanied by a life-threatening illness or accident. Indeed, there has been considerable debate devoted to whether the involvement of cunning folk in many of these cases made them particularly susceptible to witchcraft accusations. Historians such as David Harley and Willem de Blécourt, however, have convincingly argued that only a small number of cunning folk were convicted of witchcraft in early modern Europe.$^{17}$ Cunning folk were more likely to be involved in witchcraft convictions by identifying witches and by providing remedial solutions for bewitched patients. Because cunning folk were closely integrated into the communities in which they lived and practised, and immersed in popular beliefs about witchcraft, they were arguably more adept at understanding and dealing with perceived supernatural illness than other types of practitioners.

Keith Thomas attributed the proliferation of cunning folk in the early modern period to post-Reformation uncertainties, as familiar and comforting supernatural Catholic beliefs and practices were swept away by comprehensive religious reform, leaving people vulnerable and more inclined to turn to folk magic and healing. ${ }^{18}$ But the continuing popularity of cunning folk in England throughout the eighteenth and nineteenth centuries suggests a more dynamic and flexible idea of cunning practice. Certainly, cunning folk retained some of the old pagan ways and charms, Catholic prayers, and rituals, but there is sufficient evidence to suggest that they were also changing their practices in line with post-Reformation religious transformation. Their attraction was precisely because of this protean, chameleon quality, adapting to religious change rather than propping up dispirited, defenceless people who were struggling to cope with religious transformation. ${ }^{19}$ Historical accounts of the Earl of Derby's death give only perfunctory consideration to the cunning woman-some have ignored her completely or even questioned her existence-but her pres- 
ence allows an exploration into the relationship between cunning magic and conventional Galenic medical practice, and into the reasons for the continued popularity of cunning folk.

There are two detailed accounts of the Earl of Derby's illness and death. One is from John Stow's Annales of England, published in 1600. The other is an unsigned note, dated April 1594, in the Talbot papers (the family papers of the Shrewsburys). ${ }^{20}$ The extensive level of intricate detail in the latter indicates that it was probably written by a member of Stanley's household who attended the Earl during his last days. The two accounts are very similar; in fact, identical in many aspects. Both give a remarkably similar day-by-day description of the Earl's symptoms and treatment, followed by a list of "Reasons and Conjectures w[hi]ch caused many to suppose his Honor to bee bewitched (MS 3199, fol. $715^{\mathrm{r}}$ )." Neither version attributes the Earl's death to poison, and both focus on witchcraft as the most likely cause of his demise. Stow must have based his account on the 1594 letter, but it is likely that he consulted more than one source for his account, and it is probable that he also discussed the case with at least one of the attendant physicians. His Annales were published only a few years after the Earl's death and the account provides a level of medical detail that is quite unusual.

According to both accounts, it was initially thought that the healthy, thirty-five-year-old Earl had overexerted himself with four successive days of strenuous exercise, and something politely referred to as a "surfet," an Elizabethan euphemism for overindulgence of food and alcohol. His symptoms were "vomiting of a sower rustie matter with bloud," jaundice, weight loss, "swelling and hardnesse of the spleen," and violent hiccups (Stow, p. 1275; MS. 3199, fol. $713^{v}$ ). Violent hiccupping was often associated with demonic possession or bewitchment, but the connection was not made until later.

Physicians were quickly sent for, but they had to travel from Chester to the Earl's family home at Latham (near Ormskirk, north of Liverpool), and it would have taken at least two days for them to arrive. The distance is about 30 miles as the crow flies, but they would have had to negotiate the mouth of the 
Mersey, and crossing the fords at Hale or Runcorn would have been dependent on tides and weather conditions. ${ }^{21}$ While he was waiting, like any sensible early modern person, the Earl self-medicated. He took "a glister [an enema] to draw the course of the humors downward," followed the next day by a "gentle infusion of Rhubarb and Manna [a laxative] in a draught of chicken broth. This wrought him very well nine times (Stow, p. 1275; MS. 3199, fol. 713r)." When the physicians finally arrived, they immediately wanted to bleed him, because he was vomiting blood, but the Earl refused to allow it. Stanley also rejected the suggestion that he should swallow his own vomit in order to cleanse the lining of his stomach. So instead, the physicians commenced a regimen of purging and applied oils, and "plaisters" to his stomach, and gave him an opiate of "diascordium in syrope of limons," which enabled him to get some sleep. Four days before he died, Stanley ceased to pass urine and various methods were used to remedy this without success, including a "Catheter, which being conveied into his bladder, was strongly sucked by the Chirurgion (Stow, pp. 1275-76; MS. 3199 , fols $\left.713^{r-v}\right)$." Towards the end of his twelve-day illness the Earl begged the doctors to stop treating him and allow him to die. In his last days, he called out against witchcraft and witches and had strange visions and trances (Stow, p. 1276; MS. 3199, fol. $715^{r}$ ). Thirty years later the historian William Camden reported that Ferdinando Stanley's dead body, "though rolled in sear-clothes, and wrapped in lead, yet ranne with such corrupt and most stinking humors, that no man could in a long time come neere his place of burial."22 In both elite and popular belief, the presence of evil spirits was associated with foul smells, their presence "betrayed by some notably foul and noisome stench."23

As a member of the aristocracy, the Earl of Derby could well afford the best medical care, and had two physicians and two surgeons in attendance. ${ }^{24}$ The medical detail given is meticulous and includes the number of his stools (29), and the number of times he vomited (52), as well as a vivid description of their smell, colour, and consistency. The persistent purging was meant to be beneficial and was supposed to restore the humoral balance, though it is more probable that it actually hastened his death. But while he rejected some of the doctors' more stringent recommendations, Stanley was not averse to trying esoteric and expensive solutions, and he was using "Bezars stone, and Unicornes horne" for the duration of his illness (Stow, p. 1276; MS. 3199, fol. 713 v). These were medicinal, not magical compounds, considered to act as potent panaceas against poison. Unicorn's horn (probably some sort of ground bone or fossil) 
was on the official drugs lists for pharmacists until 1745; the Bezar Stone was found in the intestines of grazing animals. Numerous early modern medical texts attest to their powerful properties as medical antidotes to poison. ${ }^{25}$

The two accounts of the Earl's death diverge at the point where the physicians entered the sick-chamber. According to Stow's account, which appears to be relaying information from one of the attendant physicians, they discovered a wise woman, "[a] homely woman, about the age of fiftie yeares, ... mumbling in a corner of his honors chamber (Stow, p. 1277)." She was straining herbs in a pot and chanting incoherent blessings. The Talbot letter, however, makes no mention of a cunning woman. But, given the time that it took them to arrive, it is hardly surprising that the family called in a local healer. Cunning folk were ubiquitous in the early modern community, and not restricted to poor and uneducated people. The anonymous author of the letter may have been reluctant to reveal that the family had consulted a magical healer in case it led to trouble. In some quarters the Stanley family was suspected of having Catholic sympathies. ${ }^{26}$

The connection between "magical" or "superstitious" practices of cunning folk and Catholicism would have made aristocratic families particularly careful about admitting to consulting cunning folk, especially towards the end of the sixteenth century when questions about the Royal succession had become particularly vexing. The Earl's mother, Margaret Clifford, had once written about her use of cures prepared by a cunning man after conventional remedies had failed to help her health problems. Some members of her household, she said, had recommended a man named Randall, who had a special remedy for easing the "sickness and weakness in ... [her] body and limbs ... by applying outward things." ${ }^{27} \mathrm{He}$ stayed in her house for several months, until she incurred the displeasure of the Queen for meddling in sorcery. According to the official version, Randall was an astrologer whom the Countess consulted to determine by means of witchcraft how long the Queen would live. ${ }^{28}$ Under the parliamentary act passed in 1581, it was a felony to predict the length of the queen's reign by "witchcraft, conjurations, or other like unlawful means." ${ }^{29}$ Margaret Clifford had to resort to writing begging letters to Francis Walsingham in an attempt to return to the Queen's good favour; letters in which she claimed to have discovered that Randall was a sorcerer, who "lived in great wickedness," and had been spreading slanderous rumours about her intentions towards the Queen. ${ }^{30}$ This reflects the ambivalence of elite attitudes towards cunning folk: they sought out 
their services when it suited them, but vilified them when necessary to protect their own interests.

In other cases, unscrupulous "magical" practitioners were quick to take advantage of their wealthy but gullible high-born clients, and played upon their weaknesses. Alec Ryrie has recently recorded an account of Henry, Lord Neville, the eldest son and heir to the earl of Westmorland, and his encounter, beginning in 1544, with the sorcerer, physician, and cloth-dyer, Gregory Wisdom. ${ }^{31}$ Lord Henry had accumulated extensive gambling debts, and, in desperation to find a solution, consulted the sorcerer in the hope of extricating himself from his debts. Wisdom offered to make Lord Neville a magic ring which guaranteed better luck with the dice. In return, Neville promised to pay Wisdom a pension of ten pounds a year, as well as several marks for immediate expenses. According to Neville's confession, Wisdom also offered to summon "the god Orpheus" to endow him with the ability to the play the lute "as well ... as any man in England," to find buried treasure beneath a wayside cross in the north of England, and to cast a spell to bring about the deaths of Neville's wife and father, so that Neville could remarry and inherit the family wealth. ${ }^{32}$ As we only have Lord Henry's version of events, it is impossible to know the extent of Wisdom's unscrupulousness, but there must have been cunning folk who were only too ready to exploit the weaknesses of their aristocratic clients and dupe them into parting with their money.

Nevertheless, when afflicted by serious, mysterious illnesses, even the highest-born families were tempted to resort to counter-magic. The response of the physicians to the presence of a cunning woman in the Earl of Derby's chamber is particularly revealing. They turned the wise woman out of the room, but later used her presence to change their diagnosis. They said the woman told them the Earl was "strongly bewitched [and] seemed often to ease his honor both of his vomiting and hickocke, but ... when ... hee was eased, the woman her selfe was troubled most vehemently in the same manner, the matter which she vomited, being like also unto that which passed from him (Stow, p. 1277)." They were referring to transference, one of the more mysterious forms of healing used by cunning folk; the belief that the cunning woman could "take the disease herself or transfer it to some Dog, or Brute." ${ }^{33}$

Thus the physicians used the presence of the cunning woman, not to suggest that she had bewitched him, but to argue that the Earl had died because he was bewitched. Scholars have suggested that Stow highlighted the physicians' 
declaration of bewitchment in order to obscure the possibility of poisoning. Jeffcoate proposes that Stow had been ordered by "people in high places" to deflect attention from the real cause of death. ${ }^{34}$ But if that were the case, surely Stow would not have mentioned the unicorn's horn and bezar stone; early modern readers would have immediately made the connection with poison. It seems more likely that they wanted to allay any blame attached to losing such an important and influential patient. If the Earl had some sort of gastric disorder exacerbated by alcohol abuse, it is possible that the treatment of the physicians actually aggravated the renal failure that killed him. ${ }^{35}$ The somewhat dubious status of physicians in Elizabethan society would have accentuated this concern, particularly in the light of their shadowy reputation as conspirators, and even poisoners, in their role as court physicians. ${ }^{36}$ In 1594, the same year as the Earl of Derby's death, Queen Elizabeth's physician and a member of the College of Physicians, Dr Rodrigo Lopez, was incarcerated in the Tower of London, allegedly involved in a conspiracy to poison the Queen. ${ }^{37}$ Thus physicians found cunning folk useful as a means of manipulating their diagnoses where problematic and politically contentious illnesses were concerned.

The popularity of cunning folk with ordinary people, as well as patronage by members of elite families, increased the opposition of civil and religious authorities. Godly clerics abhorred cunning folk, and suggested they were exploiting vulnerable people who were terrified of witches. They realized, however, that the attraction of cunning folk was because their "magical" cures actually worked, or at least seemed to work. The parish minister Henry Holland, for instance, acknowledged that cunning folk "can and will cure the sick," and appear to "doe no man harme, but much good." 38 The clergyman George Gifford, who is credited by historians with having a firmer grasp on popular mentalities than most of his learned contemporaries, well understood the lure of cunning folk. ${ }^{39}$ One of the characters in his Dialogue Concerning Witches tells the story of a man whose ten-year-old daughter was "taken lame" with severe back pain. He consulted a local wise woman with an excellent reputation for healing, who told him that he had a bad neighbour, and that the child was "forspoken" or bewitched. ${ }^{40}$ She gave him a remedy and the girl recovered completely. Therein lay the dilemma for Gifford, and other members of the Anglican clergy, who were seeking to dissuade people from consulting cunning folk for problematic illnesses: an innocent neighbour was accused of witchcraft, but the girl recovered her health. 
Renowned for terrifying sermons in which they preached hellfire and damnation, zealous Protestants were adamant in their condemnation of cunning folk, and constructed a frightening, powerful, and omnipresent devil, adamantly asserting that consulting magical practitioners was part of the devil's plan to capture their souls. ${ }^{41}$ In their writings, sermons, and legal statutes the authorities desperately tried to discourage the use of magical folk remedies. Richard Bernard, in his book of advice to jurymen serving on witch trials, declared that all witches were in league with the devil. He called for their execution, including the "good or white witches commonly called blessers, healers, cunning wise men or women." ${ }^{2}$ But attempts to label cunning folk as diabolical never gained currency at the popular level. For many, the Protestant alternative of prayer, fasting, and piety was inadequate when faced with severe, sudden, or unusual illness. The "magical" elements of cunning practice had considerable popular appeal and people from all levels of society continued to seek their help in times of illness and distress.

\section{III}

The most distinctive characteristic of cunning practice was the identification of a supernatural cause for a patient's suffering: the suggestion that a sick person was possessed by an evil spirit, overlooked, "forspoken" or bewitched. The cunning folk's approach to healing was to use magical rituals and charms to break the spell, often with herbal remedies. Some of these rituals and charms were clearly derived from the old religion; entreaties to saints and sacred relics, such as crucifixes and holy water, were sometimes in view. In 1661 a midwife believed to have skill in the art of magical healing, Mrs Pepper from Newcastle, was consulted to treat a pitman, Robert Pyle. He was very ill, suffering from bad headaches with fits of shaking and trembling; symptoms that she interpreted as bewitchment. A witness at the York Assizes, in 1665, said that Mrs Pepper sprinkled Pyle with holy water, which she placed "upon a red hott spott which was upon the back of his right hand," and placed a silver crucifix on his hand, chest, and mouth. ${ }^{43}$ These were the types of practices that the Church authorities were particularly anxious to eradicate-Latin prayers, sacraments, and saints of popular Catholic worship—the "superstitious" practices of magical healing. ${ }^{44}$ Indeed, it was usually the trappings of Catholicism that got cunning folk into 
trouble, and brought them to the attention of the courts. It was most likely the use of religious charms in this case that led to Mrs Pepper's indictment.

Such types of practices drew most attention from the courts and therefore appeared more prevalent than they actually were. Cunning folk, in fact, employed a wide variety of methods when it came to healing. They used a combination of liturgy and adjurations derived from both Christian and pagan sources. Protestant influences, also, were clearly apparent in their practices, not least in the popular recognition of the power of the spoken word. Spoken and chanted prayers were considered a compelling means of healing, and were a fusion of indigenous practices and Christian devotion. Thus popular magic absorbed practices from a wide range of influences: arcane pre-Christian knowledge and skills passed on through oral traditions; Catholicism, and Biblecentred Protestantism; as well as vernacular texts more commonly associated with high magic. The appeal of such healing practices, while numinous and fundamental to the popularity of cunning folk, was not necessarily attached to a particular religion. ${ }^{45}$

Cunning folk were sought out for help with suspected supernatural afflictions because they were believed to possess esoteric knowledge about herbal remedies that were especially efficacious against witchcraft. There was a range of herbs reputed to be effective, both as protection and remedy. These included mistletoe, snapdragon, mandrake, hazel, and vervain. ${ }^{46}$ William Drage, who practised as a physician and apothecary for many years, based his Daimonomageia "on numerous well-authenticated case studies from different places and times, and by his own first-hand experience." ${ }^{37} \mathrm{He}$ was convinced that the "magical" skills used by cunning folk were the only solution for supernatural afflictions.$^{48}$ He reported instances of cunning folk using "[h]erbs ... boiled in a Pot, over which the bewitched do hold their head, when the fit approaches." ${ }^{49}$ The intent was to drive the evil spirits from the body of the afflicted patient. The purging of evil humors with herbal emetics and infusions was ubiquitous and common to both academic and folk medicine.

Cunning practice had much in common with Paracelsian and occult medicine. Occult medicine relied upon "Words, Characters, and Herbs," and was applied to the art of harnessing the gifts of nature for healing..$^{50}$ The possibility of healing from a distance through the sympathetic or magnetic qualities of the surrounding elements was, increasingly in the seventeenth century, given credence by Paracelsians and filtered into a more general appreciation 
of magical healing and the practices of cunning folk. Paracelsus's notion that a disease "caused by incantation, ... must be cured by incantation" was comfortably absorbed into folk medicine, although without the same intellectual justification. ${ }^{51}$ The witch hunter John Stearne, for instance, attributed cunning folk with using the "weapon salve," and said they had the ability to cure by "anointing the Instrument which gave the wound to cure the wound."52 Although rejected by conventional Galenists and the Church, intellectual justification of remedies based on the sympathetic properties of the elements gave cunning magic greater credibility. Remedies involving the four elements-earth, fire, air and water-abounded in the healing practices of cunning folk.

A vital component of cunning practice was the use of something intimately connected to the victim of witchcraft, such as their clothing, hair, fingernail parings, or urine. Washing the clothes of the victim in running water was practised in the belief that evil spirits could be transferred to the water and washed away. Burning items of intimate apparel worn next to the skin, or burying them in the ground, was another approach. The patient's urine was frequently incorporated into remedies for witchcraft. The cunning woman Anne Greene deposed at the Yorkshire assizes, in 1654, that in order to cure a client's "paines in the head she requires their water and a locke of their haire," which she boiled together and then threw on the fire. ${ }^{53}$ Boiling the patient's urine, together with pins, nail parings, and hair of the victim, was a common remedy against witchcraft that was also adopted by astrological physicians, such as Simon Forman and William Lilly. ${ }^{54}$ Lilly provided a scientific explanation of how such treatments worked: "these are naturall experiments, and work by sympathy" in order to torment the witch and draw her out of hiding, which then, in theory, brought relief to the victim. ${ }^{55}$

Many supernatural diseases were perceived to have been caused by the circulation of deleterious vapours and odours between the witch and her victim, and so it is not particularly surprising that people believed supernatural afflictions could be healed in a similar manner. One of the more esoteric methods of healing used by cunning folk was known as transference. The Earl of Derby's cunning woman, as we have seen, allegedly transferred Stanley's illness onto herself. Mrs Pepper used a different approach. She placed a young child and a baby on her patient's mouth, claiming that "the breath of the children would suck the evill spiritt out of him." ${ }^{56}$ Another method was through the intermediary of animals. In Northumberland, in 1604, cunning women Kath- 
erine Thompson and Anne Nevelson were presented in the ecclesiastical courts for using "white ducks or drakes and to sett the bill therof to the mouths of the sicke person and mumble uppe their charmes." ${ }^{37}$ This appears to have been a talent with the potential to make cunning folk particularly vulnerable to suspicions of witchcraft, since it reputedly enabled them to cause supernatural affliction as well as cure it. It must have been their popularity at the village level, as well as the ambivalence of elites, that protected them, to some extent, from accusations of witchcraft.

\section{IV}

This ambivalence can best be seen in the relationship between cunning folk and conventional, university-educated physicians. Some physicians were deeply opposed to the practices of cunning folk. The Northampton physician John Cotta counselled against cunning folk: "by hallowed herbes and salves, and other superstitious ceremonies, [they] promise to allay and calm divels, practices of other witches, and the forces of many diseases." ${ }^{58} \mathrm{He}$ recounted a personal experience at Pychley, in 1602, when a wise woman was consulted in a case of suspected bewitchment. A young boy was suffering from severe convulsions, "drawing his head and heeles violently backward," and in considerable pain. Cotta was present during the wise woman's consultation, along with several other observers. Her "cunning," which had something to do with a "kercher," was, according to Cotta, a complete failure. He did not give details of the attempted remedy, but a common method of magical diagnosis was to examine an item of clothing that had been in close contact with the patient's body, in the belief that it would sympathetically reflect the state of their health. ${ }^{59}$ Cotta said the boy later "voyded a great and long worm," after which he completely recovered. ${ }^{60}$ His objection to cunning folk was that they were ignorant and superstitious.

In some cases, however, physicians actively encouraged the consultation of cunning folk. In 1604, Doctor Bracegirdle, a fellow of Brasenose College with over 30 years of medical experience, told Brian Gunter that he would be wasting his time and money to consult more doctors for his daughter Anne, who was suffering from "strange fits." He said that Anne was bewitched and "having no skill to redresse it," the family would be better off to consult cunning 
men. ${ }^{61}$ Gunter sought the services of John Wendow of Newbury, "being a p[er] son supposed to be cunning in matters conc[er]ning witchcrafte." 62 Wendow quickly determined that Anne Gunter was bewitched by some evil neighbour, and her condition improved when the thatch from the roof of the suspected witch's house was burned. Bracegirdle noted the improvement and interpreted this as confirmation that Anne Gunter's illness was supernatural in origin and said that he was not qualified to deal with it. ${ }^{63}$ Burning the thatch, or a tile, from the roof of a suspected witch was supposed to confirm the witch's identity and relieve the suffering of the victim. ${ }^{64}$ Like the Earl of Derby's physicians, Bracegirdle seems to have been motivated here by self-interest. The Gunter case was contentious and some people believed that Gunter had encouraged his daughter to fake her symptoms in order to justify his accusations of witchcraft against an antagonistic neighbour. Thus Bracegirldle, who had known the Gunters for many years and had a personal connection to the family, may have been reluctant to oppose Gunter's accusations of witchcraft. ${ }^{65}$ It could well be that passing on the responsibility to cunning folk was, for some physicians, a convenient way to circumvent perplexing or controversial cases of witchcraft and supernatural affliction.

The rivalry and divisions between different types of medical practitioners were not as prevalent as the writings of physicians such as John Cotta would have us to believe. While Cotta was intent on keeping medical practice in the hands of university-educated physicians, the College of Physicians was not particularly interested in pursuing alleged cunning people. ${ }^{66}$ Although they did take issue with an irregular practitioner, Mrs Woodhouse, who, in 1596, claimed to be able to diagnose pregnancy by inspecting urine with 96 percent accuracy, and cure many people bewitched by sorcery or the stars, they appeared indifferent to her magical activities. Members of the College of Physicians were far more concerned with unlicensed practitioners using practices based on Galenic medical theory, such as bloodletting, and the use of purges and emetics to restore humoral balance. Mrs Woodhouse, according to College records, had given erroneous and fatal advice on bloodletting and had prescribed remedies such as stibium and mithridate for fever, which had resulted in her patient almost dying. ${ }^{67}$ In 1623 , a healer, Robert Booker, came to the attention of the College when he determined that John Parker of St Martin's Lane was bewitched, and anointed him with oil, using a verbal charm in an attempt to cure him. The College agreed that Parker's symptoms were strange 
and said that witchcraft may have been involved, but claimed that Booker did not have witchcraft skills. ${ }^{68}$ University-educated physicians were well aware of the need for special skills when dealing with supernatural afflictions, but did not regard cunning folk as a particular threat to their practices. Furthermore, in most cases, learned physicians and cunning folk were dealing with patients at opposite ends of the social scale.

Educated medical opinion was therefore ambivalent about cunning folk. Certainly, there may have been cases where physicians reported cunning folk to the authorities for poaching their patients, and many were of the opinion that cunning folk lacked the necessary skill and knowledge "to prescribe or give fitting, proper and convenient medicines, for the cure of any disease." ${ }^{\prime 9} \mathrm{But}$ other educated people claimed that cunning folk were actually more successful in their cures than physicians. The philosopher Francis Bacon suggested that "empirics and old women are more happy many times in their cures than learned physicians, because they are more exact and religious in holding to the composition and confection of tried medicines." Learned physicians, according to Bacon, had an arrogant tendency to alter required amounts, "adding and making changes to their receipts at their pleasure." ${ }^{70}$ The astrological physician, Nicholas Culpeper, was highly critical of learned physicians, especially those from the London College of Physicans. Not only was he scathing about their methods, but he also said their medicines were "dear and scarce to find." ${ }^{11}$ Many of Culpeper's remedies were similar to those used by cunning folk, and, as he made abundantly clear, cost considerably less and were more successful than those used by physicians. Opposition to conventional medicine can also be seen in the case of Elizabeth Jennings, who, in 1622, was suffering from very severe symptoms of bewitchment. When a neighbour, Margaret Russell, discovered the physicians' "intention of letting blood," she argued against it "w[i]th much earnestness ... saying the doctors wold kill her." ${ }^{\text {"2 }}$ She sought out alternative remedies from a wide range of healers, including cunning folk, who confirmed her suspicions of bewitchment and suggested some herbal remedies. There was, then, some criticism of the conventional medical approach to supernatural afflictions and a demonstrated preference for the more innocuous treatments of cunning folk.

Of far greater concern to conventional physicians than cunning folk was the use of Paracelsian remedies by rival practitioners. This can particularly be seen in James Primrose's medical treatise, De Vulgi in Medicina Errobus, pub- 
lished in English as Popular Errours or the Errours of the People in Physick in 1651. The front piece shows an angel holding back, not a cunning woman, but a charitable gentlewoman- "Loe here a woman comes in charitie / To see the sicke, and bring her remedie." ${ }^{73}$ According to the accompanying text, the gentlewoman refuses herbal remedies from the "Pothecaries shoppe," and offers the patient a "pepper posset" and an "antimonial cup." The antimonial cup was a Paracelsian metallic remedy, heralded by its inventor, John Evans, as a panacea for a variety of ailments, such as stomach problems, gout, agues, plagues, fever, that "helpeth against ... madnesse \& frenzie ... Poysons, and Venemous corruptions." ${ }^{74}$ Primrose was far more concerned about practitioners like Evans than he was about cunning folk. ${ }^{75}$ Primrose, who is best known for his fierce support of Galenism in opposing William Harvey's theory of circulation of the blood, was, in fact, notably silent on the practices of cunning folk, such as divination. He, like Cotta, was trying to establish a monopoly for orthodox, university-educated physicians. ${ }^{76}$ The College of Physicians regarded Evans as a "dangerous charlatan" after two of his high status patients died from severe vomiting, allegedly after using his remedy. ${ }^{77}$ Evans's use of Paracelsian remedies, though, was bound to attract the umbrage of the College, and there is no indication that they considered him a "magical" practitioner.

While some historians have described Evans as a cunning man, there is little evidence that his contemporaries regarded him in this light. ${ }^{78}$ Like his contemporary, the astrological physician Richard Napier, Evans was a clergyman who practised astrological physic and described himself as a "Minister, and Preacher of Gods Word." ${ }^{\prime 79} \mathrm{He}$ was well educated, and obtained a Master of Arts degree from the University of Oxford in $1621 .{ }^{80}$ Evans's pupil, William Lilly, wrote at some length about Evans in his autobiography and referred to him as a competent astrologer, albeit with a somewhat disreputable reputation, and never, at least in print, referred to him as a cunning man. ${ }^{81}$ Evans, in fact, like many practitioners of medicine, straddled both worlds between medicine and magic. Some cunning folk also straddled both worlds. Most were men and women of low to middle social status, but some were well-educated doctors, surgeons, clerics, and school teachers who were practising as cunning folk in order to supplement their incomes ${ }^{82}$ Furthermore, as Davies has shown, many cunning folk were literate and possessed scholarly texts on magic and astrology. ${ }^{83}$ Thus, it is not always easy for historians to make the distinction between cunning folk, and astrological and occult physicians. 
Ronald Sawyer has suggested that many of the clients who consulted Richard Napier, the astrological physician, regarded him as a cunning man. ${ }^{84}$ As far as his clients were concerned, he did much the same things: listened to their suspicions of witchcraft, and gave them herbal remedies and amulets to protect them from supernatural harm. Napier, though, would have rejected this epithet. As a learned astrologer and alchemist, he sat comfortably in the realms of hermetic magic, with his arcane Latin manuscripts and patronage from powerful people. ${ }^{85}$ As Davies says, there is danger in "underestimating popular perspicacity ... cunning folk and astrologer-physicians were seen differently in terms of social position and skills, and consequently people would have interacted differently with each type." ${ }^{86}$ Some seventeenth-century commentators, however, such as John Brinley, did not discriminate between cunning folk and astrologers in condemning their "unlawful Arts." ${ }^{87}$ The gap between popular and elite cultures may have widened over the course of the seventeenth century, but the boundaries between high and low magic, between academic medicine and cunning practice, were at times indistinct.

Arguably, though, the most significant distinction between cunning practice and Galenic medicine was its Anglo-Saxon antecedents. Folk medicine was not wedded to the invasive, harmful treatments associated with Galenic medicine and did not engage as readily with the theory of humoral balance..$^{88}$ When it came to supernatural afflictions, cunning folk offered people a level of comfort and security that was absent from Galenic treatment. Purging may well have been commonplace, but it does not appear to have been as prevalent in cunning practice as it was in orthodox medicine. Some cunning folk, in fact, gained reputations as esteemed healers, because of their ability to heal without purging. In 1652, when a man was grievously tormented with intolerable pain in the head for a period of five weeks, and thought to be bewitched, many doctors tried to treat him "without redress." Joan Peterson, a healer of good repute, gave him a drink which cured without purging. When she was later tried at the Old Bailey for administering a potion to Lady Powell, who died soon after drinking it, it was recorded that several physicians and surgeons testified in her favour, and said the causes of Lady Powell's death "were the Dropsie, the Scurvey, and the yellow Jaundies, and that they wondered how she was able to live so long [about 80], having most of these diseases growing on her for many years before. ${ }^{90}$ While this was a controversial case, even the pejorative accounts 
admitted that Joan Peterson was a skilled healer, and many of the attendant physicians spoke in her favour.

While some of the treatments used by cunning folk may have had genuine therapeutic benefits, there were, more likely, what we would now call placebo or psychological factors involved. George Gifford suggested that cunning folk frightened people into believing they were bewitched and then cured them by alleviating their fears. ${ }^{91}$ Robert Burton, author of The Anatomy of Melancholy, believed that both natural and supernatural diseases could be healed by the "Force of Imagination:" the "Charmes" used by cunning folk "forceth a motion of the humors, spirits, and blood, which takes away the cause of the malady from the parts affected." 92 Although, he said, "there is no vertue in such Charmes," they worked because people believed in them - "the patient puts his co[n]fidence" in such remedies. According to Burton, this was due to "opinion alone, faith;" hence cunning folk "doth more strange cures then a rationall Physition." ${ }^{93}$ While scholars like Gifford and Burton felt that cunning folk were exploiting witchcraft fears in the community, many people believed that their magical remedies and charms were the only means to combat the tangible and pervasive danger of witches, who could inflict terrible afflictions on people with their curses, spells, and magical potions and poisons. ${ }^{94}$

The Earl of Derby's excruciating, lingering death was an extreme case that warranted extreme measures from the attendant physicians. Their reaction to the presence of the wise woman in the Earl's chamber demonstrates their expedient avoidance of a difficult and awkward situation. But her presence confirms that cunning folk were readily accessible and sought out by people at all levels of society. Furthermore, the "magical" element of their cures gave cunning folk a decided advantage over conventional practitioners. Cunning magic was therefore often deemed preferable to the orthodox methods of the licensed physicians, which so often proved inadequate in the face of the plethora of supernatural illness that inflicted people in early modern England. The complex, vexatious nature of supernatural afflictions in the prevailing religious and political environment of post-Reformation England engendered considerable challenges for medical and religious authorities, creating an environment where people from all levels of society were more inclined to seek help from cunning folk. 


\section{Notes}

1. Ferdinando Stanley was the great-grandson of Mary Brandon, Henry VIII's younger sister.

2. John Stow, The Annales of England: Faithfully Collected out of the Most Autenticall Authors, Records, and other Monuments of Antiquitie, Lately Corrected, Encreased and Continued from the first Inhabitation until this Present Yeare 1600 (London, 1600), p. 1276.

3. William Jeffcoate, "Why did the $5^{\text {th }}$ Earl of Derby die?" The Lancet 357 (2001), pp. 1876-79. Extreme thirst is a symptom of arsenic poisoning but is not listed by Stow as one of Stanley's symptoms.

4. Shortly after he became Earl of Derby, Ferdinando Stanley was approached by Catholic conspirators to take over the English throne. Stanley refused and turned in the conspirators; the ring leader, Richard Hesketh, the alchemist and associate of John Dee, was tortured and executed. Stanley's poisoning was thought to be a revenge killing. See David Brinson, "Hesketh (1553-1593)," in Oxford Dictionary of National Bibliography, ed. H. C. G. Matthew and Brian Harrison (Oxford: Oxford University Press, 2004; online ed.) [hereafter ODNB]

5. Henry VIII's Witchcraft Act of 1542 was repealed by Edward VI; when Elizabeth I came to the throne there was no Witchcraft Act. A new Witchcraft Act was initiated in 1563; see especially Marion Gibson (ed.), Witchcraft and Society in England and America 1550-1750 (London: Continuum, 2003), p. 1.

6. See for instance, John Jewel, Certaine Sermons Preached Before the Queenes Majestie, and at Paules Crosse, by the Reverend Father John Jewel Late Bishop of Salisburie (London, 1583), [M6 ]; "John Jewel to Peter Martyr, Nov 2, 1559," in The Zurich Letters, Comprising the Correspondence of Several English Bishops and Others, ed. Hastings Robinson, The Parker Society (Cambridge: Cambridge University Press, 1842), pp. 44-45.

7. See Owen Davies, Popular Magic: Cunning-Folk in English History (London; New York: Hambledon Continuum, 2007), p. viii. First published as Cunning-Folk: Popular Magic in English History (London; New York: Hambledon Continuum, 2003).

8. While it is difficult to give a precise sense of their numbers, Alan Macfarlane found that "nowhere in Essex was there a village more than ten miles from a known cunning man," in Witchcraft in Tudor and Stuart England: A Regional and Comparative Study (London, Routledge \& K. Paul, 1970), p. 120. 
9. See especially, Philip C. Almond (ed.), Demonic Possession and Exorcism in Early Modern England: Contemporary Texts and their Cultural Contexts (Cambridge: Cambridge University Press, 2004), especially pp. 8-12; Thomas Freeman, "Demons, Deviance and Defiance: John Darrell and the Politics of Exorcism in late Elizabethan England," in Conformity and Orthodoxy in the English Church, c. 1560-1660, ed. Peter Lake and Michael Quester (Woodbridge, Suffolk; Rochester, NY: Boydell Press, 2000), pp. 34-63; Nathan Johnstone, The Devil and Demonism in Early Modern England (Cambridge: Cambridge University Press, 2006), pp. 60106; Michael MacDonald's introduction to Witchcraft and Hysteria in Elizabethan London: Edward Jorden and the Mary Glover Case (London; New York: Tavistock; Routledge, 1991), especially pp. xix-xxvi; James Sharpe, Instruments of Darkness: Witchcraft in Early Modern England (Philadelphia: University of Pennsylvania Press, 1996), pp. 194-95; D. P. Walker, Unclean Spirits: Possession and Exorcism in France and England in the Late Sixteenth and Early Seventeenth Centuries (London: Scholar Press, 1981), especially pp. 43-49, 61-73.

10. For the increasing tendency to blame witches for demonic possession, see especially Sharpe, Instruments, pp. 190-210; Richard Raiswell (with Peter Dendle), "Demon Possession in Anglo-Saxon and Early Modern England: Continuity and Evolution in Social Context," in Journal of British Studies 47 (2008), pp. 738-67(p. 759).

11. "Superstition" was a mutable concept in early modern Europe. The term was frequently used pejoratively to dismiss the religious beliefs of one's opponents. Protestant reformers applied the term to the beliefs and practices associated with the old religions, both Catholic and pagan. The term could also be applied to those expressing excessive religiosity or using "legitimate" religious practices for inappropriate purposes, such as magical healing; see especially, Andrew Cambers, "Demonic Possession, Literacy and 'Superstition' in Early Modern England," Past and Present 202 (2009), pp. 3-35; Helen Parish and William G. Naphy (ed.), Religion and Superstition in Reformation Europe (Manchester: Manchester University Press, 2002); Stuart Clark, "Protestant Demonology: Sin, Superstition, and Society (c.1520-c.1630), in Early Modern European Witchcraft: Centres and Peripheries, ed. Bengt Ankarloo and Gustav Henningsen (Oxford: Clarendon Press, 1990), pp. 45-81.

12. In recent years, medical historians have shifted focus away from the approved practitioners of health and medicine-physicians, surgeons, apothecaries and midwives - to give much needed attention to the numerous "irregular" practitioners, particularly women, who were practising medicine in early modern England; 
see especially, Margaret Pelling (with Frances White), Medical Conflicts in Early Modern England: Patronage, Physicians, and Irregular Practitioners, 1550-1640 (Oxford: Clarendon Press, 2003). For a useful overview on the scholarship in this area, see Mark S. R. Jenner and Patrick Wallis, "The Medical Market Place" in Medicine and the Market in England and its Colonies, c.1450-c.1850, ed. Mark S. R. Jenner and Patrick Wallis (Basingstoke [England]; NewYork: Palgrave Macmillan, 2007), pp. 1-23.

13. Willem de Blécourt, "Witch Doctors, Soothsayers and Priests. On Cunning Folk in European Historiography and Tradition," Social History 19 (1994), pp. 285-303 (p. 288); see also Ronald Hutton, The Triumph of the Moon: a History of Modern Pagan Witchcraft (Oxford: Oxford University Press, 1999), p. 84.

14. Emma Wilby has taken an anthropological approach in Cunning Folk and Familiar Spirits: Shamanistic Visionary Traditions in Early Modern British Witchcraft and Magic (Brighton; Portland: Sussex Academic Press, 2005); for a psychosocial approach, see Edward Bever, The Realities of Witchcraft and Popular Magic in Early Modern Europe: Culture, Cognition, and Everyday Life (Basingstoke, England; New York: Palgrave Macmillan, 2008), pp. 219-334.

15. Davies, Popular Magic, especially pp. xi-xiv.

16. See especially, Keith Thomas, Religion and the Decline of Magic: Studies in Popular Beliefs in Sixteenth and Seventeenth Century England (New York: Charles Scribner's Sons, 1971), pp. 553-57, 561-67, 582; Macfarlane, Witchcraft, pp. 170-76, 195-98; Robin Briggs, Witches and Neighbours: The Social and Cultural Context of European Witchcraft, $2^{\text {nd }}$ ed. (Oxford: Blackwell, 2002), passim; Malcolm Gaskill, Crime and Mentalities in Early Modern England (Cambridge, UK; New York: Cambridge University Press, 2002), pp. 33-119; James Sharpe, "Disruption in the Well-Ordered Household: Age, Authority, and Possessed Young People," in The Experience of Authority in Early Modern England, ed. by Paul Griffiths et al. (New York: St Martin's Press, 1996), pp. 187-212. Legal studies of early modern English witchcraft have also emphasized the domestic nature of witchcraft accusations; see Clive Holmes, "Women: Witnesses and Witches," Past and Present 140 (1993), pp. 45-78; James Sharpe, "Women, Witchcraft and the Legal Process," in Women, Crime and the Courts in Early Modern England, ed. Jennifer Kermode and Garthine Walker (Chapel Hill; London: University of North Carolina Press, 1994), pp. 106-24.

17. For contestation of the view that many of the women accused as witches were cunning women and midwives, see especially David Harley, "Historians as De- 
monolgists: The Myth of the Midwife-Witch," Social History of Medicine 3 (1990), pp. 18-20; Willem de Blécourt, "Witch Doctors, Soothsayers and Priests. On Cunning Folk in European Historiography and Tradition," Social History 19 (1994), pp. 285-303 and "Cunning Women, From Healers to Fortune Tellers," in Curing and Insuring Essays on Illness in Past Times: The Netherlands, Belgium, England and Italy, $16^{\text {th }}-20^{\text {th }}$ Centuries, ed. Hans Binneveld and Rudolf Dekker (Hilversum, The Netherlands: Verloren, 1993), pp. 43-55. For support, see especially Richard A. Horsley, "Who Were the Witches? The Social Roles of the Accused in the European Witch Trials," Journal of Interdisciplinary History 9 (1979), pp. 689-715; Norman Cohn, Europe's Inner Demons: An Enquiry Inspired by the Great Witch-Hunt (New York; Scarborough, Ontario: Meridian, 1975), p. 249; Gábor Klaniczay, The Uses of Supernatural Power: The Transformation of Popular Religion in Medieval and Early-Modern Europe, trans. Susan Singerman, ed. Karen Margolis (Cambridge: Polity Press, 1990).

18. Thomas, pp. 493-501.

19. See also Judith Bonzol, “The Other Sort of Witches': Cunning Folk and Supernatural Illness in Early Modern England," (unpublished PhD thesis, University of Sydney, 2010), p. 242.

20. Lambeth Palace Library, Talbot Papers 1570-1599, MS. 3199, fols 713-718.

21. For a description of a journey from Chester to Liverpool in the early modern period, see Richard Trench, Travellers in Britain: Three Centuries of Discovery (London: Aurum Press, 1990), p. 92.

22. William Camden, Annals, or, The Historie of the Most Renowned and Victorious Princesse Elizabeth, Late Queen of England Containing all the Important and Remarkable Passages of State Both at Home and Abroad, During her Long and Prosperous Reigne, trans. R. N. Gent (London, 1635), p. 436. It should be noted that Camden thought Stanley had been poisoned rather than bewitched, but he said that the "stinking humors" were attributed to witchcraft.

23. Nicolas Remy, Demonolatry: an Account of the Historical Practice of Witchcraft (1595), ed. Montague Summers, trans. E. A. Ashsin (New York: Dover, 2008 [first published 1930]), Book I, Chapt. X, p. 38.

24. Their names were Canon, Joynar, Bate and Case; a Richard Joyner, a Fellow of Corpus Christi, Oxford, received an MD at Cambridge University in 1580 in Venn, John and J. A. Venn. Alumni Cantabrigienses: A Biographical List of all Known Students, Graduates and Holders of Office at the University of Cambridge from Earliest Times to 1900 (Cambridge: Cambridge University Press, 1922), vol. 1, p. 491. 
25. Nicholas Culpeper listed unicorn horn not only as an antidote to poison, but also as a diuretic and general restorative. He described bezar stone as "good for fevers, pestilence, and consumptions," as well as an antidote to poison, in Pharmacopoeia Londinensis: or the London Dispensatory (London, 1654), pp. 66, 70. Nicholás Monardes described "Bezaar stones," as "the moste principall remedie that we knowe nowe, and that which hath doane best effect, in many that have beene poisoned," in Joyfull Newes out of the Newe Founde Worlde, trans. John Frampton (London, 1577), fol. 99v. James Primrose said that Bezar "comforts the heart by an occult, and not a manifest qualitie;" he was dubious about the existence of the unicorn, but conceded that some animals' horns have the potential to act as an antidote against poison, in Popular Errours or the Errours of the People in Physick, trans. Robert Wittie (London, 1651), pp. 356-70. [First published as De Vulgi in Medicina Errobus Libri Quatuor ... (London, 1638)]. Two bezar stones listed as stolen from the house of Sir Thomas Vachell in 1613 were valued at $£ 5$; see County of Middlesex. Calendar to the Sessions Records: New Series, Vol. 1: 1612-14, ed. William Le Hardy (London, 1935), pp. 32-33.

26. Ferdinando's father was accused of being negligent in prosecuting his Catholic friends as recusants; see Louis A. Knafla, "Stanley (1531-1593)" in ODNB.

27. From a letter written from the Countess of Derby to Francis Walsingham, May 1580, in Nicholas Harris Nicolas, Memoirs of the Life and Times of Sir Christopher Hatton, K.G., Vice Chamberlain and Lord Chancellor to Queen Elizabeth. Including his Correspondence with the Queen and other distinguished Persons (London: Richard Bentley, 1874), pp. 146-47.

28. As a direct descendant of Henry VII the Countess of Derby was a contender to the English throne; see Barry Coward, The Stanleys, Lord Stanley, and Earls of Derby 1385-1672: The Origins, Wealth and Power of a Landowning Family (Manchester, UK; Dover, N.H., USA: Published for the Chetham Society by Manchester University Press, 1983), p. 144.

29. In Philip Tyler, "The Church Courts at York and Witchcraft Prosecutions 15671640," Northern History 4 (1969), p. 84.

30. Nicolas, pp. 146-47.

31. Alec Ryrie, The Sorcerer's Tale: Faith and Fraud in Tudor England (Oxford: Oxford University Press, 2008).

32. The account comes from Neville's confession given from debtors' prison, in Ryrie, pp. 1-33. 
33. William Drage, Daimonomageia: A Small Treatise of Sicknesses and Diseases from Witchcraft and Supernatural Causes (London, 1665), p. 21.

34. Jeffcoate, p. 1879.

35. Jeffcoate says that the Earl's symptoms are in keeping with an "upper gastrointestinal disorder" or "bacterial food poisoning," but dismisses it because Stow made no mention of anyone else being infected. The letter, however, relates that the Earl's wife had consulted Doctor Case and was "given physicke" the week before Stanley's illness, LPL, MS. 3199, fol. 713.

36. Camden, p. 430. See also Margaret Pelling, "Compromised by Gender: The Role of the Male Medical Practitioner in Early Modern England," in The Task of Healing: Medicine, Religion and Gender in England and the Netherlands, 1450-1800, ed. Hillary Marland and Margaret Pelling (Rotterdam: Erasmus Publishing, 1996) p. 105; William Birken, "The Social Problem of the English Physician in the early Seventeenth Century," Medical History 31 (1987), pp. 214-15.

37. For a detailed description of the Lopez poison conspiracy, see David S. Katz, The Jews in the History of England, 1485-1850 (Oxford; New York: Clarendon Press; Oxford University Press, 1994), pp. 49-97.

38. Henry Holland, A Treatise Against Witchcraft (Cambridge, 1590), G1 ${ }^{\text {r }}$; see also William Perkins, A Discourse of the Damned Art of Witchcraft: So Farre Forth as it is Revealed in the Scriptures, and Manifest by True Experience (Cambridge, 1608), p. 174-76.

39. George Gifford, A Dialogue Concerning Witches and Witchcrafts (London, 1593), A3; Alan Macfarlane, "A Tudor Anthropologist: George Gifford's Discourse and Dialogue," in The Damned Art: Essays in the Literature of Witchcraft, ed. Sydney Anglo (London: Routledge \& Kegan Paul, 1977), pp. 140-55.

40. Gifford, $B^{r}$.

41. See for instance, Holland, F4. See also Johnstone, p. 135.

42. Richard Bernard, A Guide to Grand-Jury (London, 1627), pp. 129, 184-87.

43. The National Archives, Kew, Assizes, Northern and North-eastern circuits: Criminal depositions and case papers [hereafter ASSI], 45/7/2/103.

44. See especially, Tudor Church Reform Henrician Canons of 1535 and the Reformation Legum Ecclesiasticarum, ed. Gerald Bray, Church of England Society (Woodbridge, Surrey: The Bydell Press, 2000), p. 27.

45. Ronald Hutton applies this argument to more general folk beliefs in "The English Reformation and the Evidence of Folklore," Past and Present 148 (1995), pp. 89-116. 
46. British Library, Sloane MS 1783, fols 69-75, "Remedies for Witchcraft."

47. Bernard Capp, “Drage, William (bap. 1636, d. 1688)," in ODNB.

48. Drage, p. 39.

49. Drage, p. 20.

50. W. W., Occult Physick, or the Three Principles in Nature Anotomized by Philosophical Operation, Taken from Experience (London, 1660), pp. 1, 2, 4, 125; see also, Hardwick Warren, Magick and Astrology Vindicated From those False Aspersions and Calumnies, which the Ignorance of Some hath Cast Upon Them (London, 1651), p. 3.

51. Paracelsus, cited in Robert Burton, The Anatomy of Melancholy, What it is. With All the Kindes, Causes, Symptomes, Prognostickes, and Severall Cures of it (Oxford, 1621), p. 290.

52. John Stearne, A Confirmation and Discovery of Witchcraft (London, 1648), p. 10.

53. ASSI $45 / 5 / 1 / 39$.

54. William Lilly, Christian Astrology Modestly Treated in Three Books (London, 1647), pp. 464-66, 468-69. For Forman's remedies for witchcraft, see Barbara Howard Traister, The Notorious Astrological Physician of London: Works and Days of Simon Forman (Chicago; London: University of Chicago Press, 2001), especially p. 117; Lauren Kassell, Medicine and Magic in Elizabethan London Simon Forman: Astrologer, Alchemist, and Physician (Oxford: Clarendon Press, 2005), especially p. 188.

55. Lilly, p. 466.

56. ASSI $45 / 7 / 2 / 103$.

57. Peter Rushton, "Women, Witchcraft, and Slander in Early Modern England: Cases from the Church Courts of Durham, 1560-1675," Northern History 18 (1982), pp. 116-32 (p. 120).

58. John Cotta, A Short Discoverie of the Unobserved Dangers of Severall Sorts of Ignorant and Unconsiderate Practisers of Physicke in England (London, 1612), p. 71.

59. Matilda Allin of Dullingham in Cambridgeshire was charged, in 1592, with carrying "kerchiefs, fillets, girdles and partlets from divers sick persons" and taking them to cunning folk for healing purposes, in Thomas, p.184.

60. Cotta, p. 72.

61. National Archives, Kew, Records of the Court of Star Chamber, STAC 8/4/10, fol. $141^{\mathrm{v}}$.

62. STAC $8 / 4 / 10 / 97^{\mathrm{r}}$.

63. STAC $8 / 4 / 10 / 141^{v}$. 
64. See, for instance, William Lilly, Doctor Lillys Last Legacy: Being the Poor Mans Physician, the Sick Mans Friend, and the Country-Man's Doctor (London, 1683), pp. 3-4; Joseph Blagrave, Blagraves Astrological Practice of Physick (London, 1671), pp. 154-56.

65. For more detail on the Anne Gunter case, see James Sharpe, The Bewitching of Anne Gunter: A Horrible and True Story of Deception, Witchcraft, Murder and the King of England (New York: Routledge, 2001); Judith Bonzol, “The Medical Diagnosis of Demonic Possession in an Early Modern English Community," Parergon 26 (2009), pp. 115-40.

66. Pelling, Medical Conflicts, pp. 197, 213.

67. Margaret Pelling and Frances White, "WOODHOUSE, Mistress," in Physicians and Irregular Medical Practitioners in London 1550-1640: Database, 2004. http:// www.british-history.ac.uk. Despite its exotic and magical-sounding name, mithridate was a medicinal treatment used by regular practitioners; John Hall, for example, used mithridate in a mixture with "London Treacle" and "conserve of wormwood" to treat a severe case of colic, in John Hall, Select Observations on English Bodies of Eminent Persons in Desperate Diseases, trans. James Cook (London, 1679), pp. 9-10.

68. Pelling, Medical Conflicts, p. 220; "BOOKER, Robert," in Pelling, Physicians.

69. Edward Poeton, “The Winnowing of White Witchcraft," British Library, Sloane MS 1954, fol. $170^{\mathrm{v}}$.

70. Francis Bacon, The Works of Francis Bacon, ed. James Spedding, Robert Ellis and Douglas Heath (London, 1858), vol. 4, p. 388 [translation of De Augmentis Scientiarum (1623)].

71. Nicholas Culpeper, The English Physitian Enlarged and Now Made a Very Necessary Part of the Physitians Library that will Cure all Diseases (London, 1661) p. 15.

72. British Library, Additional MS 36674, fol. 134, "Papers Relating to Alleged Witchcraft Practised upon Elizabeth Jenyns."

73. Primrose, $[\mathrm{A}]^{\mathrm{v}}-[\mathrm{A} 2]^{\mathrm{r}}$.

74. John Evans, The Universall Medicine: or the Vertues of the Antimoniall Cup (London, 1651), A3 ${ }^{v}$. Earlier editions were destroyed by Archbishop Laud at the bequest of the College of Physicians, see Bernard Capp, "Evans, John (b. 1594/5?, d. in or after 1659)" in ODNB.

75. See also Primrose's attack on Evans in The Antimoniall Cup Twice Cast, trans. from Latin by Robert Wittie (London, 1640).

76. William Birken, "Primrose, James (1600-1659)," in ODNB. 
77. Capp, “Evans.”

78. See for instance, Patrick Curry, Prophecy and Power: Astrology in Early Modern England (Cambridge: Polity Press, 1989), p. 28. Curry has repeated the epithet "wise or cunning-man" to describe Evans in "Lilly, William (1602-1681)" in $O D N B$, but Bernard Capp's entry for John Evans describes him as an "astrologer and medical practitioner.

79. See the title page of John Evans, Collected out of the Experiments, and Observations of the Most Famous, Learned, and Best Approved Philosophers, and Physicians (London, 1634).

80. Capp, "Evans.”

81. William Lilly, Mr Lilly's History of his Life and Times: Written by Himself. Published from the Original Manuscript (London, 1721), p. 21, 24.

82. See especially, Macfarlane, Witchcraft, pp. 117-18, 127.

83. Davies, Popular Magic, pp. 68-69; see also Owen Davies, Grimoires: A History of Magic Books (Oxford: Oxford University Press, 2009), p. 67.

84. Ronald C. Sawyer, Patients, Healers and Disease in the South East Midlands, 1597-1634 (unpublished PhD Dissertation, University of Wisconsin-Madison, 1986)," p. 149.

85. Michael MacDonald, Mystical Bedlam: Madness, Anxiety, and Healing in Seventeenth-Century England (Cambridge: Cambridge University Press, 1981), especially pp. $16-17$.

86. Davies, Popular Magic, p. 80.

87. John Brinley, A Discovery of the Impostures of Witches and Astrologers (London, 1680), p.5.

88. See M. L. Cameron, Anglo-Saxon Medicine (Cambridge: Cambridge University Press, 1993), pp. 159-68. Cameron (p. 168) argues that the recipients of AngloSaxon medicine had a greater chance of recovery because they would not have died from loss of blood or infection, but his argument that Anglo-Saxon medicine was "about as good as anything prescribed before the mid-twentieth century" has recently been challenged by Barbara Brennessel et al, "A Reassessment of the Efficacy of Anglo-Saxon Medicine," Anglo-Saxon England 34 (2005), pp. 183-96.

89. See Anon., The Tryall and Examination of Mrs. Joan Peterson, before the Honorable Bench, and the Sessions House in the Old-Bayley (London, 1652), p. 8.

90. Anon., A Declaration in Answer to Several Lying Pamphlets Concerning the Witch of Wapping (London, 1652), p. 7.

91. Gifford, G4. 
100 JUDITH BONZOL

92. Burton, p. 127.

93. Burton, pp. 126-27.

94. For more on supernatural afflictions and the imagination, see Judith Bonzol, "Afflicted Children: Supernatural Illness, Fear, and Anxiety in Early Modern England," in Diseases of the Imagination and Imaginary Diseases in the Early Modern Period, ed. Yasmin Haskell (Turnhout: Brepols, 2011), in press. 